\title{
The Influence of Stirring Speed, Temperature and Initial Nitrogen Concentration on Specific Anammox Activity
}

\author{
Tiago H. Martins ${ }^{1} *$, Theo S.O. Souza ${ }^{2}$, Maria Bernadete Amâncio Varesche ${ }^{1}$. \\ ${ }^{I}$ Department of Hydraulics and Sanitation, São Carlos School of Engineering, University of São Paulo, São Carlos, \\ SP, Brazil. \\ ${ }^{2}$ Department of Hydraulic and Environmental Engineering, Polytechnic School, University of São Paulo, São \\ Paulo, SP, Brazil.
}

\begin{abstract}
This study evaluates the influence of initial nitrogen concentration, temperature and stirring speed on specific anammox activity (SAA). The biomass was tested in single batch reactors with different initial nitrogen concentrations (Assay 1) ranging from 60 to $140 \mathrm{mg} \mathrm{N}_{\text {total }} / \mathrm{L}$ in equimolar ratio $\left(\mathrm{NO}_{2}^{-}-\mathrm{N}_{\mathrm{N}} \mathrm{NH}_{4}^{+}-\mathrm{N}\right)$ and in another test to $67.3 \mathrm{mg} \mathrm{NH}_{4}^{+}-\mathrm{N} / \mathrm{L}$ and $92.2 \mathrm{mg} \mathrm{NO}{ }_{2}^{-}-\mathrm{N} / \mathrm{L}$ (close to anammox stoichiometric ratio). The anammox biomass was also tested in single batch at different temperatures (from 20 to $37^{\circ} \mathrm{C}$ ) to determine the short-term effects on SAA (Assay 2). In the third assay the stirring speed ranged from 50 to $150 \mathrm{rpm}$ in a sequencing batch reactor (SBR) at $37^{\circ} \mathrm{C}$. SAA was affected by the stoichiometric molar ratio but not by equimolar initial concentrations. The maximum specific anammox activities were $26.2 \mathrm{mg} \mathrm{NH}_{4}^{+}-\mathrm{N} / \mathrm{g}$ VSS.h in the single batch reactor at $37^{\circ} \mathrm{C}$ with $\mathrm{NO}_{2}{ }^{-} \mathrm{N}^{-} \mathrm{NH}_{4}{ }^{+}-\mathrm{N}$ stoichiometric ratio and $33.5 \mathrm{mg} \mathrm{NH}{ }_{4}^{+}-\mathrm{N} / \mathrm{g}$ VSS.h in the $\mathrm{SBR}$ at $37^{\circ} \mathrm{C}$ and $50 \mathrm{rpm}$. The $\mathrm{NO}_{2}^{-}{ }^{-} \mathrm{N} / \mathrm{NH}_{4}{ }^{+}-\mathrm{N}$ molar ratio affected specific anammox activity, and SAA showed to be more hindered by low increases of stirring speed than reported in the literature.
\end{abstract}

Key words: SBR, ammonium, nitrite, specific anammox activity, anammox

\footnotetext{
*Author for correspondence: dr.thmartins@gmail.com
} 


\section{INTRODUCTION}

The pollution caused by nitrogen compounds, mainly characterized by an excess of ammonium used in fertilization practices, is a subject of great concern. The nitrogen released into the environment affects the biogeochemical cycles by stimulating photosynthetic organisms that fix carbon, increasing biomass concentration in water bodies and consequently causing eutrophication.

The conventional nitrification-denitrification processes play an important role in removing nitrogen from wastewater ${ }^{1}$. Besides the classical nitrification, ammonium $\left(\mathrm{NH}_{4}{ }^{+}\right)$can also be oxidized in anoxic environments in a process known as anammox (anaerobic ammonium oxidation), coupled to nitrite $\left(\mathrm{NO}_{2}{ }^{-}\right)$reduction. This process applies autotrophic nitrogen removal in wastewater under anaerobic conditions, and is advantageous in environments containing low levels of readily biodegradable organic matter ${ }^{2,3}$. Since it requires that approximately half of the $\mathrm{NH}_{4}{ }^{+}-\mathrm{N}$ is oxidized partially to $\mathrm{NO}_{2}^{-}-\mathrm{N}$ in a preceding nitrification step for producing an anammoxsuitable influent, the process greatly reduces the oxygen demand ${ }^{4}$. Moreover, given that anammox bacteria do not require organic matter and the process presents low sludge production, from the viewpoint of environmental preservation, it is considered as a sustainable anaerobic wastewater treatment for nitrogen removal processes.

Strous et al. ${ }^{5}$ estimated the anammox stoichiometry based on mass balance on anammox enriched cultures, as shown in Eq. 1. The anammox physiology was studied by Strous et al. ${ }^{6}$ in batch reactors. The specific anammox activity (SAA) obtained was $1.1 \mathrm{~g} \mathrm{NH}_{4}{ }^{+} \mathrm{N} / \mathrm{g}$ protein. day. Concentrations of up to $1 \mathrm{~g} \mathrm{~N} / \mathrm{L}$ in ammonium or nitrate forms did not inhibit anammox activity. However, values above $100 \mathrm{mg} \mathrm{NO}{ }^{-}-\mathrm{N} / \mathrm{L}$ (for several days) inhibited the process. Moreover, the addition of $1.4 \mathrm{mg} \mathrm{N} / \mathrm{L}$ hydrazine and $0.7 \mathrm{mg} \mathrm{N} / \mathrm{L}$ hydroxylamine (intermediate compounds of the anammox process) reestablished metabolism.

$$
\stackrel{1 \mathrm{NH}_{4}{ }^{+}+1,31 \mathrm{NO}_{2}^{-}+0,045 \mathrm{HCO}_{3}^{-} \longrightarrow}{\longrightarrow} \overrightarrow{\mathrm{CH}}_{2} \mathrm{O}_{0,5}+1,045 \mathrm{~N}_{2}+0,22 \mathrm{NO}_{3}^{-}+0,04 \mathrm{H}_{2} \mathrm{O}+0,09 \mathrm{OH}^{-}
$$

Egli et al. ${ }^{7}$ enriched a culture with $88 \%$ of anammox bacteria (determined using quantifying FISH method) in a rotating biological contactor treating ammonium-rich leachate. The culture was tolerant to up to $182 \mathrm{mg} \mathrm{N}-\mathrm{NO}_{2}{ }^{-} / \mathrm{L}$, which is a higher value than that observed for Brocadia anammoxidans. However, the catalytic anammox activity was 20 times smaller than B. anammoxidans.

The first studies on anammox showed enhanced activities at higher temperatures, in the range of 37 to $40{ }^{\circ} \mathrm{C}^{8,9}$. Dalsgaard and Thandrup ${ }^{10}$ reported anammox activity in marine sediments ranging from 6.5 to $35.7^{\circ} \mathrm{C}$. In long-term tests using a SBR, Dosta et al. ${ }^{11}$ and Hu et al. ${ }^{12}$ showed SAA between 12 and $30^{\circ} \mathrm{C}$.

Aside from nitrite concentration and temperature, many other factors affect the anammox process, such as ammonium concentration, organic matter, salinity, heavy metals, phosphate and sulfide ${ }^{13,14}$. Moreover, visible light and stirring speed are also known to influence anammox activity ${ }^{4}$.

Among them, operational conditions such as initial nitrogen concentration, temperature and stirring speed are particularly important, and must be studied systematically. In this context, the present work aimed to assess the specific anammox activity varying these three parameters. Its experimental determination was conducted by measuring the specific nitrogen compounds consumption under these different conditions to obtain information about how they influence the anammox process and to provide data that could be used to improve systems using this biotechnology. 


\section{MATERIAL AND METHODS}

Biomass from a 5-litre sequencing batch reactor (SBR) enriched for anammox was used as inoculum source ${ }^{15}$, and contained $0.6 \mathrm{~g}$ VSS/L. The SBR was fed with synthetic medium according to Graaf et al. ${ }^{8}$. Assays 1 and 2 were carried out as single batch tests using the same synthetic medium in $250 \mathrm{~mL}$ flasks filled with $90 \mathrm{~mL}$ of medium and $10 \mathrm{ml}$ of anammox biomass. The influence of different parameters on anammox activity was evaluated as described in Table 1. The initial nitrogen concentrations applied to the SBR enrichment were the same used in Assay 2 and also used by Dosta et al. ${ }^{11}$ in SAA temperature tests.

The short-term experiments with different concentrations of nitrogen compounds and temperature (Assays 1 and 2) were performed in triplicate. Assays 1 and 2 were carried out at $37^{\circ} \mathrm{C}$ and the temperature in Assay 2 was tested between 20 to $37^{\circ} \mathrm{C}$ (Table 1).

Table 1. Parameters evaluated in specific anammox activity assays

\begin{tabular}{|c|c|c|}
\hline $\begin{array}{c}\text { Nitrogen concentration } \\
\text { (Assay 1) } \\
\left(\mathrm{mg} \mathrm{NO}_{2}^{-}-\mathrm{N} / \mathrm{L} / \mathrm{mg} \mathrm{NH}_{4}^{+}-\mathrm{N} / \mathrm{L}\right) \\
\end{array}$ & $\begin{array}{c}\text { Temperature } \\
\text { (Assay 2) } \\
\left(70 \mathrm{mg} \mathrm{NO}_{2}^{-}-\mathrm{N} / \mathrm{L} \text { and } 70 \mathrm{mg} \mathrm{NH}_{4}^{+}-\mathrm{N} / \mathrm{L}\right)\end{array}$ & $\begin{array}{c}\text { Stirring speed } \\
\text { (Assay 3) } \\
\text { (Specific Power) } \\
\end{array}$ \\
\hline $31.6 / 32.8$ & $37^{\circ} \mathrm{C}$ & $50 \mathrm{rpm}\left(0.008 \mathrm{~kW} / \mathrm{m}^{3}\right)$ \\
\hline $73 / 67$ & $35^{\circ} \mathrm{C}$ & $80 \mathrm{rpm}\left(0.032 \mathrm{~kW} / \mathrm{m}^{3}\right)$ \\
\hline \multirow[t]{3}{*}{$92.2 / 67.3$} & $30{ }^{\circ} \mathrm{C}$ & $100 \mathrm{rpm}\left(0.064 \mathrm{~kW} / \mathrm{m}^{3}\right)$ \\
\hline & $25^{\circ} \mathrm{C}$ & $150 \mathrm{rpm}\left(0.216 \mathrm{~kW} / \mathrm{m}^{3}\right)$ \\
\hline & $20^{\circ} \mathrm{C}$ & \\
\hline
\end{tabular}

The influence of stirring speed on anammox activity was evaluated using time profiles obtained for the SBR operated by Martins et al. ${ }^{15}$. The SBR was operated between 383 and 433 days under different stirring speeds. The SBR in standard conditions was operated continuously at $50 \mathrm{rpm}\left(0.008 \mathrm{~kW} / \mathrm{m}^{3}\right)$. During the assays to measure the influence of stirring speed, the stirring speed of the reactor was only changed during one batch cycle. The standard stirring speed was then reestablished to $50 \mathrm{rpm}$ after the test; therefore, only the short-term effects of changing the stirring speed were tested. One week after the original conditions were reestablished, the reactor was subjected to the next test.

The specific power consumption in a stirred vessel depends on the various geometrical parameters of the impeller (height (h) and diameter (d)), reactor (diameter (D) and height $(\mathrm{H})$ ), the rotating speed $(\mathrm{N})$ and the fluid properties (density $(\rho)$ and viscosity $(\mu)$ ). The calculation of the energy consumed in the stirring process depending on the rotating speed $(\mathrm{N})$ was performed according to Arrojo et al. ${ }^{16}$. The reactor was made in borosilicate glass (diameter of $20.3 \mathrm{~cm}$ and height of $17 \mathrm{~cm}$ ). A six-bladed turbine carried out the stirring at $50 \mathrm{rpm}$ (each blade with length of $6.8 \mathrm{~cm}$ and height of $2 \mathrm{~cm}$ ).

SAA was estimated from the slope of the curve describing the $\mathrm{NH}_{4}{ }^{+}-\mathrm{N}$ consumption as a function of time and related to the biomass concentration in the flasks, as shown in Eq. (2). Values of $\mathrm{k}_{\mathrm{NO2}-}$ and $\mathrm{k}_{\mathrm{N}}$ (for nitrite consumption and nitrogen production) were calculated similarly.

Analysis of ammonium, nitrate and nitrite were performed using flow injection analysis (FIA), and biomass concentration was expressed as $\mathrm{g}$ VSS/L in accordance to APHA ${ }^{17}$.

Effects of temperature on bacterial anammox activity were modeled using the integrated form of the Arrhenius equation ${ }^{18}$. The activation energy $\left(\mathrm{E}_{\mathrm{a}}\right)$ was estimated from the slope of an Arrhenius plot of $\ln (\mathrm{k})$ as a function of $\mathrm{T}^{-1}$ (Eq. 3). 
The initial nitrogen concentrations used to calculate $E_{a}$ in the Assay 2 were in according to Dosta et al. ${ }^{11}$.

$C_{n} / C_{x}=-k\left(t-t_{0}\right)+C_{n o} / C_{x}$

Where: $C_{n} / C_{x}(\mathrm{mg} \mathrm{N} / \mathrm{g}$ VSS $)=$ nitrogen concentration $\left(\mathrm{C}_{\mathrm{N}}\right)$ per unit of biomass $\left(\mathrm{C}_{\mathrm{x}}\right)$ as a function of time $(\mathrm{t}) ; k(\mathrm{mg} \mathrm{N} / \mathrm{g}$ VSS.h) $=$ zero-order kinetics constant (SAA, for $\mathrm{NH}_{4}{ }^{+}-\mathrm{N}$ consumption); $C_{n o} / C_{x}(\mathrm{mg} \mathrm{N} / \mathrm{g}$ VSS $)=$ initial nitrogen concentration $\left(C_{n o}\right)$ per unit of biomass $\left(C_{x}\right)$.

$\ln (k)=\ln (A)-\frac{E a}{R} \frac{1}{T}$

Where: A is the Arrhenius constant; $\mathrm{k}$ is the reaction rate (mg N/g VSS.h); $\mathrm{R}$ is the gas constant $(8.31 \mathrm{~kJ} / \mathrm{mol})$; and $\mathrm{T}$ is the absolute temperature $(\mathrm{K})$.

\section{RESULTS AND DISCUSSION}

\section{SINGLE BATCH ASSAYS: NITROGEN CONCENTRATION (ASSAY 1) AND TEMPERATURE INFLUENCE (ASSAY 2)}

Single batch assays were performed to verify the behavior of biomass regarding SAA under different temperatures and nitrogen concentrations. In Tests 1 and 2, in the Assay 1 series (Table 2), ammonium was not completely consumed (Figure 1 (a, b)) while in Test 3 (when nitrite concentration was increased to reach the stoichiometric ratio: $\left.1.36 \mathrm{NO}_{2}^{-}-\mathrm{N} / 1 \mathrm{NH}_{4}{ }^{+}-\mathrm{N}\right)$ both ammonium and nitrite were $100 \%$ removed (Figure 1 (c)). This phenomenon was probably due to the fact that the biomass was not subject to nitrite limiting condition, and thus the two nitrogen compounds could be completely consumed, reaching values close to zero simultaneously.

As shown in Table 2, the values of SAA and $\mathrm{k}_{\mathrm{NO} 2}$ - from Tests 1 and 2 (equimolar initial concentrations) were similar. Analysis of variance (95\% confidence) revealed that the difference between Test 1 and 2 on Assay 1 was not statistically significant, but both were statistically different from Test 3 . However, in Test 3, the SAA and $\mathrm{k}_{\mathrm{NO} 2}$ - were 23 and $30 \%$ higher than those obtained in Tests 1 and 2, respectively. This indicated that the initial concentration of the compounds in Tests 1 and 2 did not influence the SAA, but the initial molar ratio (nitrite/ammonium) had a significant influence on SAA.

Lopez et al. ${ }^{19}$ performed the start-up and enrichment of the anammox process based on the influent molar ratio of nitrite/ammonium, gradually increasing it from 0.76 to 1.32 , and exponentially increasing the nitrogen load applied from 0.01 to $1.60 \mathrm{~kg}$ $\mathrm{N} / \mathrm{d} . \mathrm{m}^{3}$. The ammonium removal efficiencies were 53,79 and $99.9 \%$ for the ratio of $0.76,1$ and 1.32, respectively, corroborating the influence of the nitrite/ammonium molar ratio on the performance of the process. However, it was not possible to compare the SAA values as a response of nitrogen molar ratios, because the authors did not present the values in specific terms.

The evaluation of temperature influence was also performed in single batch tests (Table 3). The initial nitrogen concentration of each test was approximately equal to Test 2 of Assay 1. 
SAA under different conditions

Table 2. Initial nitrogen concentration influence in Assay 1.

\begin{tabular}{ccccc}
\hline Test & $\begin{array}{c}\text { Concentration } \\
\left(\mathrm{mg} \mathrm{NO}_{2}{ }^{-} \mathrm{N} / \mathrm{L} /\right. \\
\left.\mathrm{mg} \mathrm{NH}_{4}{ }^{+} \mathrm{N} / \mathrm{L}\right)\end{array}$ & $\begin{array}{c}\text { Molar Ratio } \\
\text { (Ammonium consumed : Nitrite } \\
\text { consumed : Nitrate produced) }\end{array}$ & $\begin{array}{c}\mathrm{SAA}^{+} \\
\left(\mathrm{mg} \mathrm{NH}_{4}{ }^{-} \mathrm{N} /\right. \\
\mathrm{g} \mathrm{VSS} \text { ) }\end{array}$ & $\begin{array}{c}\text { Complete } \\
\text { Ammonium } \\
\text { consumption }\end{array}$ \\
\hline 1 & $31.6 / 32.8$ & $1: 1.24: 0.24$ & $20.1 \pm 1.2$ & No \\
2 & $73 / 67$ & $1: 1.43: 0.34$ & $19.5 \pm 1.9$ & No \\
3 & $92.2 / 67.3$ & $1: 1.38: 0.21$ & $26.2 \pm 2.1$ & Yes \\
\hline
\end{tabular}
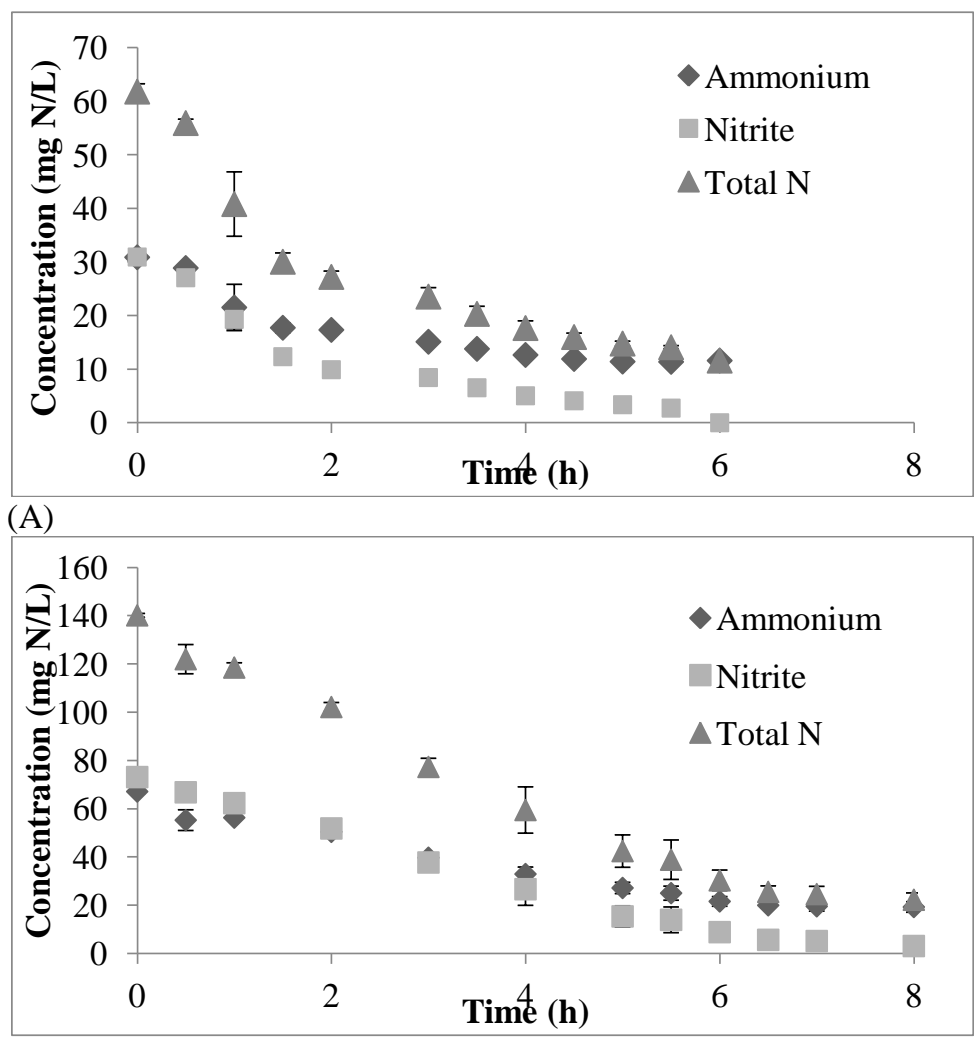

(B)

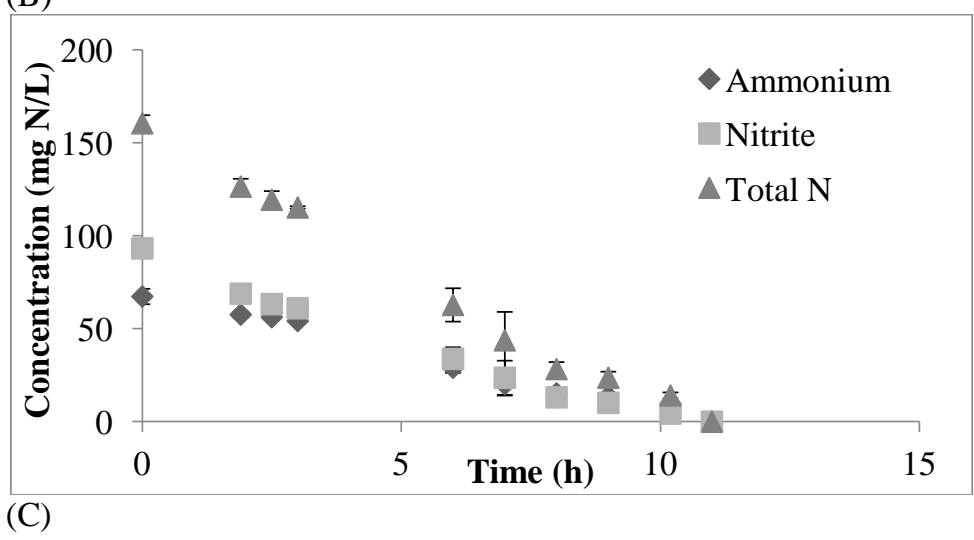

Figure 1. Temporal variation of nitrogen compounds in batch tests with (A) $32.8 \mathrm{mg} \mathrm{NH}_{4}{ }^{+}-\mathrm{N} / \mathrm{L}$ and $31.6 \mathrm{mg} \mathrm{NO}_{2}{ }^{-}$$\mathrm{N} / \mathrm{L}$, (B) $67 \mathrm{mg} \mathrm{N}-\mathrm{NH}_{4}{ }^{+}-\mathrm{N} / \mathrm{L}$ and $73 \mathrm{mg} \mathrm{NO}{ }_{2}^{-}-\mathrm{N} / \mathrm{L}$ and (C) $67.3 \mathrm{mg} \mathrm{NH}_{4}{ }^{+} \mathrm{N} / \mathrm{L}$ and $92.2 \mathrm{mg} \mathrm{NO}{ }_{2}^{-}-\mathrm{N} / \mathrm{L}$. Error bars represent the standard deviation.

At $35{ }^{\circ} \mathrm{C}$, nitrite was almost completely removed in 6 hours. The final concentration of ammonium, nitrite and nitrate were respectively $9.9 \mathrm{mg} \mathrm{NH}_{4}{ }^{+} \mathrm{N} / \mathrm{L}, 2.4 \mathrm{mg} \mathrm{NO}_{2}{ }^{-}$ $\mathrm{N} / \mathrm{L}$ and $17.4 \mathrm{mg} \mathrm{NO}_{3}{ }^{-} \mathrm{N} / \mathrm{L}$ (10 hours). The test at $30^{\circ} \mathrm{C}$ was also carried out for 10 hours, with final concentrations of $10 \mathrm{mg} \mathrm{NH}_{4}{ }^{+}-\mathrm{N} / \mathrm{L}, 5 \mathrm{mg} \mathrm{NO}{ }_{2}^{-}-\mathrm{N} / \mathrm{L}$ and $13.5 \mathrm{mg}$ $\mathrm{NO}_{3}{ }^{-} \mathrm{N} / \mathrm{L}$. In the tests at 25 and $20^{\circ} \mathrm{C}$, a much greater inhibition of anammox 
activity by low temperature was observed, mainly at $20{ }^{\circ} \mathrm{C}$. These experiments ended at 15 hours with 88 and 55\% nitrite removal and 68 and $45 \%$ ammonium removal, for 25 and $20{ }^{\circ} \mathrm{C}$, respectively.

The specific anammox activity increased gradually with temperature ranging between 20 and $35^{\circ} \mathrm{C}$, with values increasing from 1.20 to $6.6 \mathrm{mg} \mathrm{NH}_{4}{ }^{+} \mathrm{N} / \mathrm{g}$ VSS.h (Figure 2). However, there was an abrupt SAA increase at $37{ }^{\circ} \mathrm{C}$ (Test 2 of Assay 1) reaching values of $19.5 \mathrm{mg} \mathrm{NH}{ }_{4}{ }^{+} \mathrm{N} / \mathrm{g}$ VSS.h. These values are similar to those obtained by Strous et al. ${ }^{6}$ and Jetten et al. ${ }^{9}$ for optimal temperatures ranging between $37^{\circ} \mathrm{C}$ and $40{ }^{\circ} \mathrm{C}$. Table 3 shows the molar ratio on each Test. The nitrite consumption rate by anammox equation was higher than expected by the anammox molar ratio, indicating the presence of denitrifying activity in the biomass.

Egli et al. ${ }^{7}$ performed SAA assays at the following temperatures: 11, 20, 25, 30, 37 and $45{ }^{\circ} \mathrm{C}$. Maximum SAA (as $\mathrm{N}_{2}$ production rate) was observed at $37{ }^{\circ} \mathrm{C}$. No anammox activity was observed at $45^{\circ} \mathrm{C}$, and after the temperature was reduced to $37^{\circ} \mathrm{C}$ the activity could not be reestablished. At $11^{\circ} \mathrm{C}$, SAA was approximately $24 \%$ of the activity observed at $37{ }^{\circ} \mathrm{C}$. In contrast, in the Assay 2 the biomass at $20^{\circ} \mathrm{C}$ presented only $9.2 \%$ of the activity at $37^{\circ} \mathrm{C}$, under equimolar initial concentration.

Table 3. Temperature influence on Assay 2.

\begin{tabular}{cccc}
\hline $\begin{array}{c}\text { Temperature } \\
\left({ }^{\circ} \mathrm{C}\right)\end{array}$ & $\begin{array}{c}\text { Molar Ratio } \\
\text { (Ammonium consumed : } \\
\text { Nitrite consumed : } \\
\text { Nitrate produced) }\end{array}$ & $\begin{array}{c}\mathrm{SAA}^{+} \\
\text {g VSS.h) }\end{array}$ & $\begin{array}{c}\text { Complete } \\
\text { Ammonium } \\
\text { consumption }\end{array}$ \\
\hline 20 & $1: 1.47: 0.39$ & $1.8 \pm 0.3$ & No \\
25 & $1: 1.43: 0.26$ & $2.4 \pm 0.3$ & No \\
30 & $1: 1.46: 0.26$ & $4.06 \pm 0.2$ & No \\
35 & $1: 1.35: 0.45$ & $6.6 \pm 0.7$ & No \\
37 & $1: 1.43: 0.34$ & $19.5 \pm 1.9$ & No \\
\hline
\end{tabular}

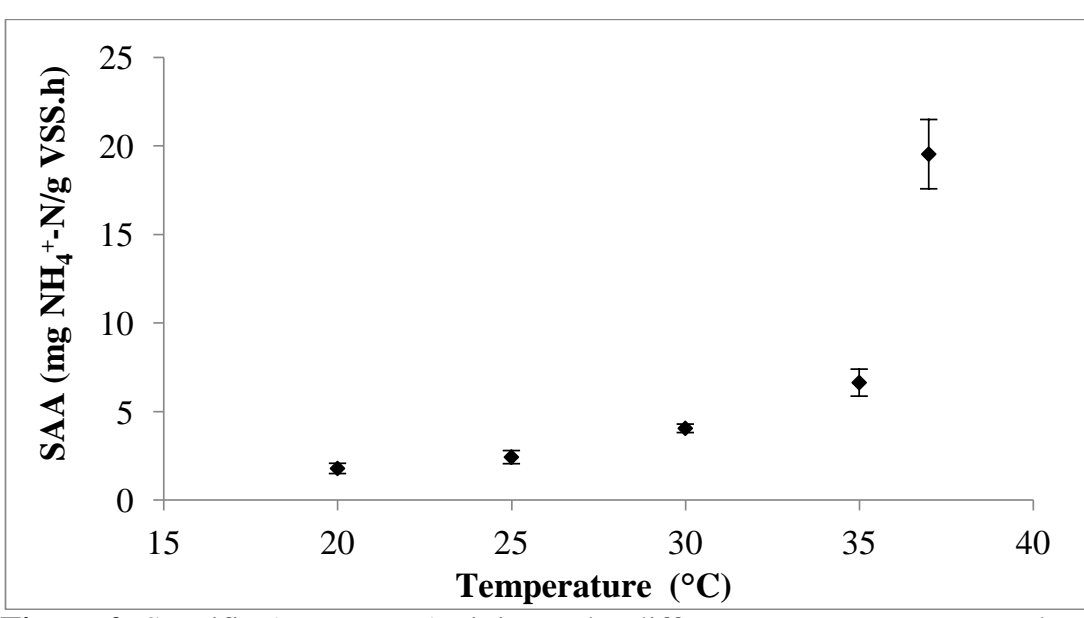

Figure 2. Specific Anammox Activity under different temperatures. Error bars represent the standard deviation.

Strous et al. ${ }^{20}$ studied the anammox process in a wastewater treatment plant sludge digester. Preliminary experiments indicated that the biomass was not inhibited by the characteristics of the effluent. $37{ }^{\circ} \mathrm{C}$ and $\mathrm{pH} 8$ were the optimum values for the anammox activity. In these physiological tests, specific anammox activity (SAA) was $0.58 \mathrm{mg} \mathrm{N}-\mathrm{NH}_{4}{ }^{+} / \mathrm{g}$ VSS.h, five times lower than the SAA of the biomass in the reactor. The biomass in the batch assays presented $78.2 \%$ of activity in the SBR.

An exponential increase of the SAA was observed for temperatures up to $37{ }^{\circ} \mathrm{C}$. Activation energy $\left(\mathrm{E}_{\mathrm{a}}\right)$ of $104 \mathrm{~kJ} \mathrm{~mol}^{-1}$ was calculated for anammox biomass 
according to the Arrhenius model (Eq. 2). The activation energies of the anammox process in other reactors treating wastewater were 63 and $70 \mathrm{~kJ} / \mathrm{mol}$, respectively ${ }^{6,11}$. The $E_{a}$ of 61 and $51 \mathrm{~kJ} / \mathrm{mol}$ in marine sediments were lower than the wastewater treatment reactors ${ }^{10,18}$.

\section{Sequencing batch (Assay 3): stirring speed influence}

The same behavior pattern of nitrogen compound concentrations was observed in all assays regarding stirring speed influence (Assay 3), with concentration increasing up to $250 \mathrm{mg} \mathrm{N}$ total $/ \mathrm{L}$ at 2.5 hours of the batch cycle, coinciding with the filling period of the reactor (Figure 3). In all assays the influent concentration was averagely $219 \mathrm{mg}$ $\mathrm{NH}_{4}{ }^{+}-\mathrm{N} / \mathrm{L}$ and $289 \mathrm{mg} \mathrm{NO}{ }_{2}^{-}-\mathrm{N} / \mathrm{L}$.

In the standard operating conditions $\left(50 \mathrm{rpm} / 0.008 \mathrm{~kW} / \mathrm{m}^{3}\right.$ ) (Figure 3 (a)), it could be observed that nitrite (limiting substrate) was consumed up to the $10^{\text {th }}$ hour. When the SBR was set to $80 \mathrm{rpm}\left(0.032 \mathrm{~kW} / \mathrm{m}^{3}\right)$, the concentration of nitrogen compounds reached a maximum of $120.1 \mathrm{mg} \mathrm{NH}_{4}^{+}-\mathrm{N} / \mathrm{L}$ and $115.5 \mathrm{mg} \mathrm{NO}_{2}^{-}-\mathrm{N} / \mathrm{L}$ in the second

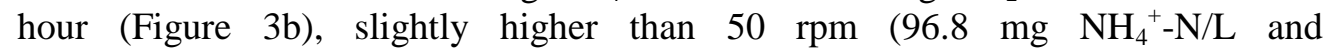
$\left.108.3 \mathrm{mg} \mathrm{NO}_{2}^{-}-\mathrm{N} / \mathrm{L}\right)$. At $100 \mathrm{rpm}\left(0.064 \mathrm{~kW} / \mathrm{m}^{3}\right)$, maximum ammonium $\left(104.5 \mathrm{mg} \mathrm{NH}_{4}{ }^{+}-\mathrm{N} / \mathrm{L}\right)$ and nitrite values $\left(144.1 \mathrm{mg} \mathrm{NO}_{2}{ }^{-} \mathrm{N} / \mathrm{L}\right)$ occurred in the second hour of the batch cycle. At the time profile of the test at $150 \mathrm{rpm}\left(0.216 \mathrm{~kW} / \mathrm{m}^{3}\right)$ (Figure 3d) maximum values of ammonium $\left(113.8 \mathrm{NH}_{4}{ }^{+}-\mathrm{N} / \mathrm{L}\right)$ and nitrite $(154.6 \mathrm{mg}$ $\left.\mathrm{NO}_{2}^{-}-\mathrm{N} / \mathrm{L}\right)$ were observed three hours after the beginning of the test.
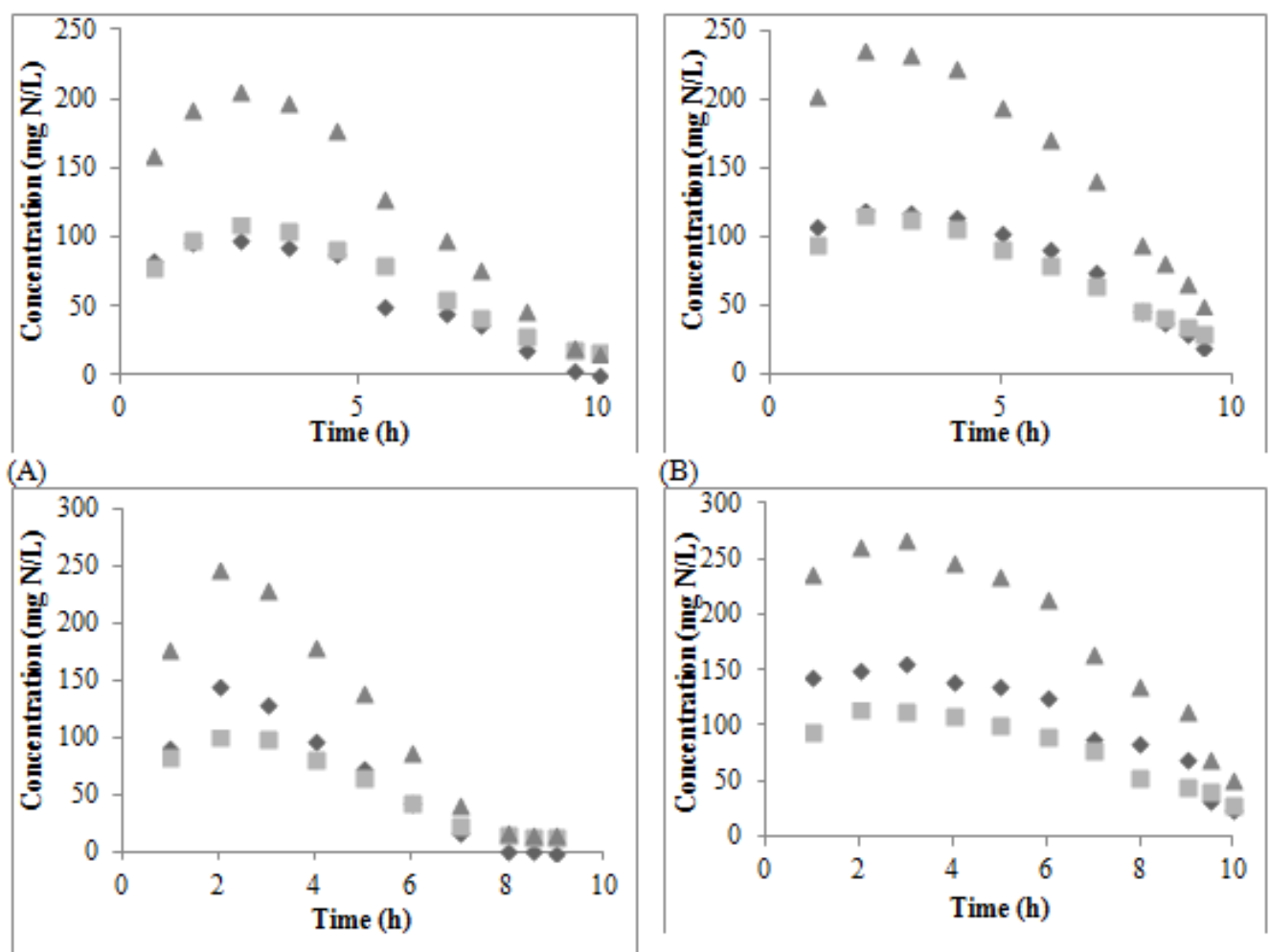

(C)

(D)

Figure 3. Temporal variation of nitrogen compounds in a SBR subjected to (A) $50 \mathrm{rpm}$, (B) $80 \mathrm{rpm}$, (C) $100 \mathrm{rpm}$ and (D) $150 \mathrm{rpm}$. Nitrite nitrogen (Squares), Ammonium nitrogen (Diamonds) and Total nitrogen (Triangles)

As shown in Tables 4 and 5, at 50rpm, values of $\mathrm{k}_{\mathrm{NO2}-}=34.8 \mathrm{mg} \mathrm{NO}{ }_{2}^{-}-\mathrm{N} / \mathrm{g}$ VSS.h and specific anammox activity SAA $=\mathrm{k}_{\mathrm{NH}_{4+}}=33.5 \mathrm{mg} \mathrm{NH}{ }_{4}^{+}-\mathrm{N} / \mathrm{g}$ VSS.h were obtained. The SAA at $80 \mathrm{rpm}$ was $28.8 \mathrm{mg} \mathrm{N}-\mathrm{NH}_{4}{ }^{+} / \mathrm{g}$ VSS.h, lower than that obtained for $50 \mathrm{rpm}$. The SAA at $100 \mathrm{rpm}$ test was $29.2 \mathrm{mg} \mathrm{NH}_{4}{ }^{+}-\mathrm{N} / \mathrm{g}$ VSS.h, and 
the $\mathrm{k}_{\mathrm{NO2}-}$ was $43.3 \mathrm{mg} \mathrm{NO}{ }_{2}^{-}-\mathrm{N} / \mathrm{g}$ VSS.h. In this case, the highest $\mathrm{k}_{\mathrm{N}}$ of all the assays tested was reached, resulting in $72.5 \mathrm{mg} \mathrm{N} / \mathrm{g}$ VSS.h (Figure 3). The SAA at 150rpm was $24.1 \mathrm{mg} \mathrm{NH}_{4}{ }^{+}$-N/g VSS h (Table 4). This test had the highest nitrate production over consumption of ammonium $\left(0.57 \mathrm{~mol} \mathrm{NO}_{3}{ }^{-} \mathrm{N} / \mathrm{mol} \mathrm{NH}_{4}{ }^{+} \mathrm{N}\right)$.

Table 4. Stirring speed influence on Assay 3.

\begin{tabular}{llll}
\hline $\begin{array}{l}\text { Stirring speed } \\
(\mathrm{rpm})\end{array}$ & $\begin{array}{l}\text { Molar Ratio } \\
\text { (Ammonium consumed } \\
\text { Nitrite consumed } \\
\text { Nitrate produced) }\end{array}$ & $\begin{array}{l}\mathrm{SAA} \\
\left(\mathrm{mg} \mathrm{NH}{ }_{4}{ }^{+}-\mathrm{N} /\right.\end{array}$ & $\begin{array}{l}\text { Complete } \\
\text { Ammonium } \\
\text { consumption }\end{array}$ \\
\hline 50 & $1: 1.32: 0.19$ & 33.5 & No \\
80 & $1: 1.33: 0.27$ & 28.8 & No \\
100 & $1: 1.4: 0.25$ & 29.2 & No \\
150 & $1: 1.44: 0.57$ & 24.1 & No \\
\hline
\end{tabular}

There was a tendency to the decrease of SAA values with increasing agitation of the SBR (Table 5). The values ranged from 33.6 to $24.1 \mathrm{mg} \mathrm{NH}_{4}{ }^{+} \mathrm{N} / \mathrm{g}$ VSS.h, when stirring speed was increased from $50\left(0.008 \mathrm{~kW} / \mathrm{m}^{3}\right)$ to $150 \mathrm{rpm}\left(0.216 \mathrm{~kW} / \mathrm{m}^{3}\right)$, respectively. However, an increase in the kinetic parameter $\mathrm{k}_{\mathrm{NO2}}$ (43.3 $\mathrm{mg} \mathrm{NO}_{2}^{-}$-N/g VSS.h) was observed at $100 \mathrm{rpm}$. In the other tests, the values remained almost constant, ranging from 34.8 to $36.9 \mathrm{mg} \mathrm{NO}_{2}{ }^{-} \mathrm{N} / \mathrm{g}$ VSS.h for 50 and $150 \mathrm{rpm}$, respectively.

Table 5. Kinetic parameters under different stirring speeds in SBR.

\begin{tabular}{cccc}
\hline $\begin{array}{c}\text { Stirring speed } \\
(\mathrm{rpm})\end{array}$ & $\begin{array}{c}\mathrm{k}_{\text {nitrite }} \\
\left(\mathrm{mg} \mathrm{NO}_{2}{ }^{-} \mathrm{N} / \mathrm{g} \text { VSS.h }\right)\end{array}$ & $\begin{array}{c}\mathrm{k}_{\text {ammonium }} \\
\left(\mathrm{mg} \mathrm{NH}_{4}^{+}-\mathrm{N} / \mathrm{g} \mathrm{VSS} . \mathrm{h}\right)\end{array}$ & $\begin{array}{c}\mathrm{k}_{\text {total N }} \\
(\mathrm{mg} \mathrm{N} / \mathrm{g} \mathrm{VSS.h})\end{array}$ \\
\hline 50 & 34.8 & 33.5 & 67.1 \\
80 & 35.5 & 28.8 & 64.2 \\
100 & 43.3 & 29.2 & 72.5 \\
150 & 36.9 & 24.1 & 61.0 \\
\hline
\end{tabular}

The increase in $\mathrm{k}_{\mathrm{NO2}-}$ at $100 \mathrm{rpm}$ was probably due to the following possibilities: (i) endogenous denitrification of biomass lysed by shearing at this stirring speed, probably by micro-organisms related to Pseudomonas sp. and Comamonas sp. present in the SBR ${ }^{15}$; and/or (ii) the $\mathrm{Ar} / \mathrm{CO}_{2}$ atmosphere in the headspace of the reactor may not have been sufficient to maintain the anaerobic agitation conditions at this speed, enabling the occurrence of nitrification by nitrite oxidizing bacteria (NOB) and subsequent reduction of nitrate, because at $100 \mathrm{rpm}$ there was no more nitrate accumulation than the one produced by the anaerobic oxidation of ammonium.

At $150 \mathrm{rpm}$, the biomass presented a different behavior. Nitratation probably occurred but there was no nitrate reduction, since in this condition there was more nitrate accumulation than expected, regarding the anammox process. It can be noted that although the values of $\mathrm{k}_{\mathrm{NO2}-}$ were similar at 50 and $80 \mathrm{rpm}$, at $80 \mathrm{rpm}$ the $\mathrm{k}_{\mathrm{NO} 2-}$ was proportionally higher than $\mathrm{k}_{\mathrm{NH} 4+}$ (SAA), indicating the favored use of nitrite compared to ammonium at higher stirring speeds (Table 5).

The molar ratio of nitrate formation should be of approximately $0.26^{5}$; however, a value of 0.57 was obtained at a stirring speed of $150 \mathrm{rpm}$ (Table 4). In addition, there were higher nitrite conversions at the two higher stirring speeds, since the nitrite / ammonium molar ratios were 1.4 and 1.44 at 100 and $150 \mathrm{rpm}$, respectively.

Arrojo et al. ${ }^{16}$ tested stirring speeds between $60 \mathrm{rpm}\left(0.003 \mathrm{~kW} / \mathrm{m}^{3}\right)$ and $180 \mathrm{rpm}$ $\left(0.09 \mathrm{~kW} / \mathrm{m}^{3}\right)$ in a SBR and observed no significant changes in SAA, but there was a significant decrease in this parameter at $250 \mathrm{rpm}\left(0.23 \mathrm{~kW} / \mathrm{m}^{3}\right)$. The authors reported 
a sharp decrease of the SAA only when the specific power was higher than 0.09 $\mathrm{kW} / \mathrm{m}^{3}$. Nevertheless, in the present study a decrease of the SAA was observed for lower ranges of specific power ( $14 \%$ when comparing 0.008 to $\left.0.032 \mathrm{~kW} / \mathrm{m}^{3}\right)$ (Table 4).

It was also observed that $154.6 \mathrm{mg} \mathrm{NO}{ }^{-}-\mathrm{N} / \mathrm{L}$ in the third hour of the batch at 150 rpm did not cause biomass inhibition. This value was higher than that reported by Strous et al. ${ }^{6}$ but lower than that one reported by Egli et al. ${ }^{7}$. The anammox biomass used by Bettazzi et al. ${ }^{21}$ showed $25 \%$ inhibition for $60 \mathrm{mg} \mathrm{NO}_{2}^{-}-\mathrm{N} / \mathrm{L}$ in short-term tests, but repeated additions of nitrite higher than $30 \mathrm{mg} \mathrm{NO}{ }^{-}-\mathrm{N} / \mathrm{L}$ caused activity losses. It was also observed that $154.6 \mathrm{mg} \mathrm{NO}_{2}^{-}-\mathrm{N} / \mathrm{L}$ in the third hour of the batch at $150 \mathrm{rpm}$ did not cause biomass inhibition. This value was higher than that reported by Strous et al. ${ }^{6}$ but lower than that one reported by Egli et al. ${ }^{7}$. Considering the studied conditions, the best stirring speed (and specific power applied) in the SBR was $50 \mathrm{rpm}\left(0.008 \mathrm{~kW} / \mathrm{m}^{3}\right)$, because increasing the applied power did not significantly increase the SAA and, for optimization purposes, $50 \mathrm{rpm}$ was sufficient for good results.

In this study, two values of the maximum specific anammox (MSAA) were determined: 1) $26.2 \mathrm{mg} \mathrm{NH}_{4}{ }^{+}$-N/g VSS.h in Test 3 of Assay 1 (in single batch), and 2) $33.5 \mathrm{mg} \mathrm{NH}_{4}{ }^{+}-\mathrm{N} / \mathrm{g}$ VSS.h (in the SBR test with stirring speed of $50 \mathrm{rpm}$ ). The MSAA was lower for single batch tests when compared to the SBR, probably due to improved agitation, enhanced mass transfer in the SBR and differences on the reactors configuration. Strous et al. ${ }^{20}$ also investigated the reason for the lower activities in experiments with single batch reactors, but did not reach any precise conclusions about this phenomenon.

The SAA values found in this study were $43 \%$ of the value obtained by Jetten et al. ${ }^{9}$. However, the SAA of $33.5 \mathrm{mg} \mathrm{NH_{4 }}{ }^{+}-\mathrm{N} / \mathrm{g}$ VSS.h obtained in assay 3 (at $50 \mathrm{rpm}$ ) was higher or close to most of the relevant data. Table 6 presents a data compilation from different SAA studies in the literature.

Table 6. Specific anammox activity values found in literature.

\begin{tabular}{llll}
\hline $\begin{array}{l}\text { Specific anammox } \\
\text { activity } \\
\left(\mathrm{mg} \mathrm{NH}_{4}{ }^{+}-\mathrm{N} / \mathrm{g} \text { VSS.h) }\right.\end{array}$ & Reactor Type & $\begin{array}{l}\text { Temperature } \\
\left({ }^{\circ} \mathrm{C}\right)\end{array}$ & Reference \\
\hline $4.25^{\mathrm{b}}$ & Batch & 35 & 22 \\
$37.1^{\mathrm{a}, \mathrm{b}}$ & Batch & 37 & 7 \\
47.91 & Gas-lift & 30 & 23 \\
7.5 & SBR 50rpm & 35 & 24 \\
27.08 & SBR 70 rpm & 35 & 24 \\
3.54 & SBR & 35 & 25 \\
3.64 & SBR 50 rpm & 35 & 26 \\
$18.33^{\mathrm{b}}$ & Batch & 35 & 27 \\
$16.67^{\mathrm{b}}$ & SBR 60-180rpm & 30 & 16 \\
$10.41^{\mathrm{b}}$ & SBR 250 rpm & 30 & 16 \\
66.67 & Fixed-bed & 37 & 28 \\
33.5 & SBR 50 rpm & 37 & This work \\
26.2 & Batch & 37 & This work \\
\hline a & &
\end{tabular}




\section{CONCLUSIONS}

The specific anammox activity increased abruptly at $37^{\circ} \mathrm{C}$. The $\mathrm{NO}_{2}{ }^{-}-\mathrm{N} / \mathrm{NH}_{4}{ }^{+}-\mathrm{N}$ molar ratio affected specific anammox activity, and SAA decreased with increasing stirring speed. For the single batch assays, $92.2 \mathrm{mg} \mathrm{NO}_{2}{ }^{-} \mathrm{N} / \mathrm{L}$ and $67.3 \mathrm{mg} \mathrm{NH}_{4}{ }^{+} \mathrm{N} / \mathrm{L}$ at $37^{\circ} \mathrm{C}$ was the best condition among the tested. The present study showed a decrease of the SAA for low increments of specific power. An increase in the value of the kinetic parameter $\mathrm{k}_{\mathrm{NO2}-}$ at $100 \mathrm{rpm}$ was observed, and for the other stirring speeds the values remained practically constant. Maximum specific anammox activity (MSAA) occurred at $50 \mathrm{rpm}$ and $37^{\circ} \mathrm{C}$ in the SBR and was $33.5 \mathrm{mg} \mathrm{NH}_{4}^{+}$$\mathrm{N} / \mathrm{g}$ VSS.h with initial concentrations close to the stoichiometric $\mathrm{NO}_{2}{ }^{-}-\mathrm{N}^{-} \mathrm{NH}_{4}{ }^{+}-\mathrm{N}$ molar ratio (1.32).

\section{ACKNOWLEDGEMENTS}

The authors gratefully acknowledge FAPESP (Fundação de Amparo à Pesquisa do Estado de São Paulo, Brazil) and CNPq (Conselho Nacional de Desenvolvimento Científico e Tecnológico, Brazil) for the financial support of this research.

\section{REFERENCES}

1- Schmidt I, Sliekers O, Schmid M, Bock E, Fuerst J, Kuenen JG, et al., New concepts of microbial treatment processes for the nitrogen removal in wastewater. FEMS Microbiol Rev. 2003; 27:481-492.

2- Strous M, Fuerst JA, Kramer EHM, Logemann S, Muyzer G, van de Pas-Schoonen KT, et al., Missing lithotroph identified as new planctomycete. Nature. 1999; 400:446-449.

3- Paredes D, Kuschk P, Mbwette TSA, Stange F, Muller RA and Koser H, New aspects of microbial nitrogen transformations in the context of wastewater treatment - A review. Eng Life Sci. 2007; 7:13-25.

4- Van Hulle SWH, Vandeweyer HJP, Meesschaert BD, Vanrolleghem PA, Dejans P and Dumoulin A, Engineering aspects and practical application of autotrophic nitrogen removal from nitrogen rich streams. Chem Eng J. 2010; 162:1-20.

5- Strous M, Heijnen JJ, Kuenen JG and Jetten MSM, The sequencing batch reactor as a powerful tool for the study of slowly growing anaerobic ammonium-oxidizing microorganisms. Appl Microbiol Biotechnol. 1998; 50:589-596.

6- Strous M, Kuenen JG and Jetten MSM, Key physiology of anaerobic ammonium oxidation. Appl Environ Microbiol. 1999; 65:3248-3250.

7- Egli K, Fanger U, Alvarez PJJ, Siegrist H, van der Meer JR and Zehnder AJB, Enrichment and characterization of an anammox bacterium from a rotating biological contactor treating ammonium-rich leachate. Arch Microbiol. 2001; 175:198-207.

8- van Graaf AA, Mulder A, Debruijn P, Jetten MSM, Robertson LA and Kuenen JG, Anaerobic oxidation of ammonium is a biologically mediated process. Appl Environ Microbiol. 1995; 61:1246-1251.

9- Jetten MSM, Strous M, van de Pas-Schoonen KT, Schalk J, van Dongen U, van de Graaf AA, et al., The anaerobic oxidation of ammonium. FEMS Microbiol Rev. 1998; 22:421-437.

10-Dalsgaard $\mathrm{T}$ and Thamdrup $\mathrm{B}$, Factors controlling anaerobic ammonium oxidation with nitrite in marine sediments. Appl Environ Microbiol. 2002; 68.

11-Dosta J, Fernandez I, Vazquez-Padin JR, Mosquera-Corral A, Campos JL, Mata-Alvarez J, et al., Short- and long-term effects of temperature on the Anammox process. J Hazard Mater. 2008; 154:688-693.

12-Hu Z, Lotti T, de Kreuk M, Kleerebezem R, van Loosdrecht M, Kruit J, et al., Nitrogen Removal by a Nitritation-Anammox Bioreactor at Low Temperature. Appl Environ Microbiol. 2013; 79:2807-2812.

13-Jin R-C, Yang G-F, Yu J-J and Zheng P, The inhibition of the Anammox process: A review. Chem Eng J. 2012; 197:67-79. 
14-Pereira AD, Leal CD, Dias MF, Etchebehere C, Chernicharo CA and de Araujo JC, Effect of phenol on the nitrogen removal performance and microbial community structure and composition of an anammox reactor. Bioresour Technol. 2014; 166:103-111.

15-Martins TH, Souza TSO and Varesche MBA, Feeding strategies for enrichment and characterization of anammox biomass in a sequencing batch reactor. American Journal of Analytical Chemistry. 2014; 5:891-900.

16-Arrojo B, Mosquera-Corral A, Campos JL and Mendez R, Effects of mechanical stress on Anammox granules in a sequencing batch reactor (SBR). J Biotechnol. 2006; 123:453-463.

17-APHA. Standard Methods for the Examination of Water and Wastewater. 19th ed. American Public Health Association / American Water Works Association / Water Environment Federation, Washington, DC, USA2005.

18-Rysgaard S, Glud RN, Risgaard-Petersen N and Dalsgaard T, Denitrification and anammox activity in Arctic marine sediments. Limnol Oceanogr. 2004; 49.

19-Lopez H, Puig S, Ganigue R, Ruscalleda M, Balaguer MD and Colprim J, Start-up and enrichment of a granular anammox SBR to treat high nitrogen load wastewaters. $J$ Chem Technol Biotechnol. 2008; 83:233-241.

20-Strous M, Van Gerven E, Zheng P, Kuenen JG and Jetten MSM, Ammonium removal from concentrated waste streams with the anaerobic ammonium oxidation (anammox) process in different reactor configurations. Water Res. 1997; 31:1955-1962.

21-Bettazzi E, Caffaz S, Vannini C and Lubello C, Nitrite inhibition and intermediates effects on Anammox bacteria: A batch-scale experimental study. Process Biochem. 2010; 45:573-580.

22-Scaglione D, Caffaz S, Bettazzi E and Lubello C, Experimental determination of Anammox decay coefficient. J Chem Technol Biotechnol. 2009; 84:1250-1254.

23-Dapena-Mora A, Campos JL, Mosquera-Corral A, Jetten MSM and Mendez R, Stability of the ANAMMOX process in a gas-lift reactor and a SBR. J Biotechnol. 2004; 110:159-170. 24-Dapena-Mora A, Van Hulle SWH, Campos JL, Mendez R, Vanrolleghem PA and Jetten M, Enrichment of Anammox biomass from municipal activated sludge: experimental and modelling results. J Chem Technol Biotechnol. 2004; 79:1421-1428.

25-Kieling DD, Reginatto V, Schmidell W, Travers D, Menes RJ and Soares HM, Sludge wash-out as strategy for Anammox process start-up. Process Biochem. 2007; 42:1579-1585.

26-Third KA, Paxman J, Schmid M, Strous M, Jetten MSM and Cord-Ruwisch R, Enrichment of anammox from activated sludge and its application in the CANON process. Microb Ecol. 2005; 49:236-244.

27-Dapena-Mora A, Campos JL, Mosquera-Corral A and Mendez R, Anammox process for nitrogen removal from anaerobically digested fish canning effluents. Water Science and Technology. 2006; 53:265-274.

28-Tsushima I, Ogasawara Y, Kindaichi T, Satoh H and Okabe S, Development of high-rate anaerobic ammonium-oxidizing (anammox) biofilm reactors. Water Res. 2007; 41:16231634 .

29-Ahn YH, Sustainable nitrogen elimination biotechnologies: A review. Process Biochemistry. 2006; 41:1709-1721. 